\title{
Hearing loss in patients using isotretinoin: is it a side effect or due to hyperlipidemia?
}

\author{
İzoretinoin kullanan hastalarda ișitme kaybı: \\ Bir yan etki mi yoksa nedeni hiperlipidemi mi? \\ O. Fatih Boztepe', Sevil Alan², Taylan Gün³, K. Murat Özcan', Ö. Erdem Gür ${ }^{5}$ \\ ${ }^{1}$ Department of Otorbinolaryngology, Anadolu Hospital, Antalya, Turkey \\ ${ }^{2}$ Department of Dermatology, Anadolu Hospital, Antalya, Turkey \\ ${ }^{3}$ Department of Otorhinolaryngology, Hayat Hospital, Gaziantep, Turkey \\ ${ }^{4}$ Department of Otorbinolaryngology, Ankara Numune Training and Research Hospital, Ankara, Turkey \\ ${ }^{5}$ Department of Otorbinolaryngology, Serik Government Hospital, Antalya, Turkey
}

\begin{abstract}
Objective: To prospectively investigate the effect of isotretinoin therapy on the functions of hearing and to show the relationship between concurrent triglyceride levels.

Methods: A total of 47 patients who were admitted to our dermatology clinic between February 2011 and June 2011 for the treatment of acne using $0.5 \mathrm{mg} / \mathrm{kg}$ isotretinoin were included in this study. All the patients were started on $0.5 \mathrm{mg} / \mathrm{kg} /$ day isotretinoin depending on their tolerance of the drug. Details such as age, sex, dose of isotretinoin for the first 6 months, monthly pretreatment and posttreatment, and ALT, AST, triglyceride and total cholesterol values were recorded. There were 33 females and 14 males in the study group.

Results: Audiometric evaluations made prior to treatment with isotretinoin, levels of PTA1 and PTA2 were 11.96 and 12.59 , respectively, these were compared with the results of tests carried out after the treatment and pre- and posttreatment values of PTA1 and PTA2 were found to be the same, 1 month after the treatment, drug use did not effect hearing. PTA 1 value after 3 months was 12.16 and PTA 2 value was 13.85. These values are compared to pretreatment values and PTA2 PTA1 both were decreased. However, in the third month the threshold decrease was not statistically significant $(p>0.05)$. PTA1 and PTA2 values after the sixth month were 12.25 and 12.96 , this decrease was statistically significant compared with pretreatment values $(\mathrm{p}<0.05)$.

Conclusion: Treatment with isotretinoin increased total cholesterol and triglyceride levels. Isotretinoin reduced pure-tone average hearing at the end of the 6th month and this effect was related to the increases in the levels of triglycerides and total cholesterol.
\end{abstract}

Key words: Acne vulgaris, drug therapy, side effects, hearing loss, hyperlipidemia.

\begin{abstract}
Özet
Amaç: Bu çalışmanın amacı, izoretinoin tedavisinin işitme fonksiyonları üzerine etkisini prospektif olarak araştırmak ve eş zamanlı trigliserit düzeyleriyle ilişkisini göstermektir.

Yöntem: Bu çalışmaya aknelerinin $0.5 \mathrm{mg} / \mathrm{kg}$ izoretinoinle tedavisi için Şubat 2011 - Haziran 2011 tarihleri arasında dermatoloji kliniğimize kabul edilen toplam 47 hasta dahil edilmiştir. İlacı tolere edebilme derecelerine göre hastaların hepsinde günlük $0.5 \mathrm{mg} / \mathrm{kg}$ izoretinoin dozuyla tedaviye başlanmıştır. Yaş, cinsiyet, ilk 6 ayda izoretinoin dozu, tedavi öncesi ve sonrası aylık AST, ALT, trigliserit ve total kolesterol değerleri kaydedilmiştir. Çalışma grubunda 33 kadın ve 14 erkek katılımcı vardı.

Bulgular: İzoretinoinle tedaviye başlamadan önce odyometrik değerlendirmeler yapılmıştır. PTA1 ve PTA2 değerleri sırasıyla 11.96 ve 12.59 idi. Bu değerler tedavi sonrası testlerin sonuçları ile karşılaştırılmış, tedavi sonrası PTA1 ve PTA2 sonuçlarının aynı olduğu saptanmıştır. İlacın kullanımı tedaviden 1 ay sonra işitmeyi etkilememişti. Üç ay sonra PTA1 ve PTA2 değerleri sırasıyla 12.16 ve 13.85 idi. $\mathrm{Bu}$ değerler tedavi öncesi değerlerle karşılaştırılmış, hem PTA1, hem de PTA2 düzeylerinin azaldığı saptanmıştır. Ancak 3 . ayda eşik değerdeki azalma istatistiksel açıdan anlamlı değildi $(\mathrm{p}<0.05)$. Altıncı aydan sonra PTA1 ve PTA2 değerleri sırasıyla 12.25 ve 12.96 idi. Tedavi öncesi değerlerle karşılaştırıldığında bu azalma anlamlıydı ( $<<0.05)$.

Sonuç: İzoretrinoinle tedavi total kolesterol ve trigliserit düzeylerini yükseltmişti. İzoretinoin 6 . ayda saf ton ortalama işitme fonksiyonlarını azaltmış olup bu etki trigliseritler ve total kolesterol düzeylerindeki artışlarla ilişkiliydi.
\end{abstract}

Anahtar sözcükler: Akne vulgaris, ilaç tedavisi, yan etkiler, işitme kaybı, hiperlipidemi.
Correspondence: Özer Erdem Gür, MD. Meltem Mah. 2. Cadde Arpet Sitesi B Blok 6/27 Antalya, Turkey.

e-mail: erdemkaptan@yahoo.com

Received: May 8, 2013; Accepted: June 3, 2013; Published online: November 1, 2013
Online available at:

www.jmedupdates.org doi:10.2399/jmu. 2013002007 QR code: 
Oral isotretinoin was approved by the FDA in 1982 for the treatment of severe acne. There is no other treatment or substitute to date and it has remained clinically the most powerful treatment against acne. Isotretinoin is a retinoid derivative and the only drug that is effective against all known major factors of acne ${ }^{[1]}$ Indications of isotretinoin treatment usually include nodular cystic acne and acne that is unresponsive to conventional therapy. The daily dose varies between 0.5 and $1 \mathrm{mg} / \mathrm{kg}$, and in order to prevent relapse a total dose of $100-150 \mathrm{mg} / \mathrm{kg}$ is recommended. ${ }^{[2]}$ As with other retinoids, the side effects of isotretinoin are divided into two groups: mucocutaneous and systemic side effects. Mucocutaneous side effects result from impairment of the production of sebum and thinning of the stratum corneum. ${ }^{[3]}$ Most patients develop drying and cracking of the skin. Cheilitis (98\%), dermatitis and facial erythema (65\%), mucositis (\% 40), conjunctivitis, blepharitis, epistaxis (35\%) and epidermal atrophy (\%25) are the most common mucocutaneous side effects. ${ }^{[1]}$ Systemic side effects affect the musculoskeletal system, gastrointestinal tract, central nervous system, eyes, ears, kidneys and thyroid gland. The most feared side effects of isotretinoin are hypertriglyceridemia (48\%) and elevations of hepatic enzymes levels (33\%). ${ }^{[4]}$ Hepatic enzyme and lipid levels have to be routinely followed-up during treatment. ${ }^{[5]}$

There are few reports on the effects of retinoids on hearing in the literature. Auditory side effects that were resolved after discontinuation of treatment are described in the literature, but the mechanism of this improvement is not known. ${ }^{[6]}$ The literature does not include any study investigating the relationship between triglyceride levels and hearing levels. This study prospectively investigated the effect of isotretinoin therapy on the functions of hearing and was intended to show the relationship with concurrent triglyceride levels.

\section{Materials and Methods \\ Patient Selection}

A total of 47 patients aged of 15-38 years who were admitted to the dermatology clinic between February 2011 and June 2011 for the treatment of acne using $0.5 \mathrm{mg} / \mathrm{kg}$ isotretinoin were included in this study. Of these, 33 of the patients were female and 14 were male. The study subjects underwent an otological examination prior to treatment. Patients with evidence of otological disease might have affected the outcomes of the study. Patients with pretreatment pure-tone audiometric thresholds lower than $25 \mathrm{~dB}$, earlier hearing problems, symptoms such as tinnitus, a history of loud noise exposure, a history of known ototoxic drug use, a history of head trauma, or autoimmune or metabolic disease, as well as patients over the age of 50 and those who did not attend follow-up appointments, were not included in the study. Patients who developed complications associated with the use of isotretinoin and patients whose treatment was halted if medically necessary were excluded.

\section{Study Design}

Written informed consent for audiometric evaluations and blood tests was taken. Pretreatment ENT examinations were performed in all patients and a detailed history was taken. In addition to routine blood tests during the treatment of patients with isotretinoin, pure-tone audiometry tests were performed prior to treatment and during the 1 st, 3rd and 6th months of treatment.

\section{Treatment and Follow-up}

All the patients were started on $0.5 \mathrm{mg} / \mathrm{kg} /$ day isotretinoin depending on their tolerance of the drug. The dosage was adjusted in patients who did not tolerate the drug. All the patients received the medication after lunch. Details such as age, sex, dose of isotretinoin for the first 6 months, monthly pretreatment and posttreatment, and ALT, AST, triglyceride and total cholesterol values were recorded; in female patients, pregnancy tests were also recorded. Patients who had elevated hepatic enzyme levels and triglyceride levels that necessitated cessation of therapy were not included in the study. During the study, when auditory symptoms occurred, audiograms and ENT examinations were repeated in addition to the routine tests.

\section{Audiometric Evaluation}

Pure-tone audiograms were performed with an Oscilla SM 950 diagnostic memory audiometer device. The tests in all patients in the control and study groups were carried out by the same audiometrist. In each case, air hearing levels of $250-8000 \mathrm{~Hz}$ and bone hearing levels of $250-4000 \mathrm{~Hz}$ were evaluated. Values of $0-25 \mathrm{~dB}$ were considered to indicate normal hearing. Audiometric values of more than $5 \mathrm{~dB}$ were considered to indicate a significant decrease. In the study and control groups, pure-tone average speech frequencies of 250-1000 and $2000 \mathrm{~Hz}$ were grouped as PTA1, and frequencies of 4000-8000 Hz were identified as high and grouped as PTA2. In this way, we aimed to evaluate the affected frequencies.

\section{Results}

There were 33 females and 14 males in the study group. The mean age was 26 (range 15 to 37 ) years. During the 
6-month follow-up, one patient experienced tinnitus around the second month but hearing loss was not detected in any of the audiometric tests. The complaint disappeared spontaneously in 3 days without the need to discontinue the drug. One patient experienced vertigo after 4 months of treatment. The patient was considered to have benign positional vertigo and was treated with maneuvers. The complaint disappeared completely, and discontinuation of the drug therapy was not necessary.

Audiometric tests were carried out at 3 months in four control patients. Sensorineural hearing loss influencing all frequencies, with no clinical manifestations, was detected in one patient at 6 months after treatment. In five patients who developed hearing loss, pure-tone hearing thresholds obtained from pre- and posttreatment audiograms were divided into two groups and evaluated. PTA1 (250-2000 $\mathrm{Hz}$ ) and PTA2 (4000-8000 Hz) are shown in Table 1 and Table 2, respectively.

In audiometric evaluations prior to treatment with isotretinoin, levels of PTA1 and PTA2 were 11.96 and 12.59 , respectively. Compared with the results of tests carried out after treatment, pre- and posttreatment values of PTA1 and PTA2 were found to be the same. Drug use did not affect hearing at 1 month after treatment. The PTA1 value after 3 months was 12.16 and the PTA2 value was 13.85. Compared to pretreatment values, both PTA2 and PTA1 were decreased. However, in the third month the threshold decrease was not statistically significant $(\mathrm{p}>0.05)$. PTA1 and PTA2 values after the sixth month were 12.25 and 12.96, respectively. The decreases compared with pretreatment values were statistically significant $(\mathrm{p}<0.05)$ (Table 3).

The levels of triglycerides and total cholesterol were significantly raised prior to treatment and 1,3 and 6 months after treatment $(\mathrm{p}<0.05)$ (Table 4).

Two-way analysis of variance was used to test the increases in total cholesterol and triglyceride levels and to investigate the relationship with hearing loss. Total cholesterol and triglyceride levels were significantly higher in patients with hearing loss.

\section{Discussion}

Although many side effects related to isotretinoin are described in the literature, the most common side effect is hyperlipidemia. In this study, the main argument is related to lipid levels. Triglyceride levels of $0-175 \mathrm{mg} / \mathrm{dl}$ are considered normal; however, triglyceride levels were over $400 \mathrm{mg} / \mathrm{dl}$ in $5 \%$ of patients in one study and in $1.5 \%$ of patients in another study.
Table 1. Pure tone audiogram - 1 values (dB-desibel).

\begin{tabular}{lcccc} 
& Pretreatment & 1st month & 3rd month & 6th month \\
\hline Case 1 & 8 & 8 & 12 & 13 \\
Case 2 & 14 & 14 & 17 & 19 \\
Case 3 & 5 & 5 & 10 & 9 \\
Case 4 & 14 & 14 & 14 & 19 \\
Case 5 & 9 & 9 & 16 & 13 \\
\hline
\end{tabular}

Table 2. Pure tone audiogram - 2 values (dB-desibel).

\begin{tabular}{lcccc}
\hline & Pretreatment & 1st month & 3rd month & 6th month \\
\hline Case 1 & 8 & 8 & 12 & 15 \\
Case 2 & 14 & 14 & 17 & 18 \\
Case 3 & 5 & 5 & 10 & 12 \\
Case 4 & 15 & 15 & 15 & 21 \\
Case 5 & 9 & 9 & 16 & 15 \\
\hline
\end{tabular}

Table 3. Average pure tone audiogram values.

\begin{tabular}{lcccc}
\hline & Pretreatment & 1st month & 3rd month & 6th month \\
\hline PTA1 & 11.96 & 11.96 & 12.16 & 12.26 \\
PTA2 & 12.59 & 12.59 & 13.85 & 12.96 \\
\hline
\end{tabular}

Table 4. Average triglyceride and total cholesterol values (mg/dl).

\begin{tabular}{lcccc} 
& Pretreatment & 1st month & 3rd month & 6th month \\
\hline Triglyceride & 70 & 72.9 & 79.2 & 91.4 \\
Total cholesterol & 170.3 & 179 & 179.8 & 190.5 \\
\hline
\end{tabular}

One of the rarest side effects is that of auditory problems. Side effects on the auditory system were first reported in 1988 by Bigby and Stern. One of the 104 side effects of isotretinoin use is decreased hearing and this decrease is considered to be probably related to isotretinoin use. ${ }^{[8]}$ In another study, 1743 patients treated with isotretinoin for various reasons were evaluated and treatment was terminated in only $1.4 \%$ of patients due to drug side effects. ${ }^{[9]}$ In a further study, based on the fact that synthetic retinoids affect neural growth and differentiation, researchers investigated the possible neurological and neurophysiological side effects of oral isotretinoin therapy. Due to the abnormal neurological and neurophysiological findings in patients who suffer numbness, paresthesia, or loss of sensa- 
tion before and during treatment with isotretinoin, more electroneuromyographic studies must be carried out. ${ }^{[10]}$ In 2005, a patient treated with the retinoid acitretin suffered bilateral sensorineural hearing loss; the patient's hearing was improved by oral steroid therapy. For this reason, acitretin is regarded as an ototoxic drug. ${ }^{[6]}$ In 2011, a patient aged 15 years who was being treated with $0.5 \mathrm{mg} / \mathrm{kg}$ isotretinoin experienced bilateral hearing loss and tinnitus during the sixth week of therapy. The hearing loss was found in audiometric tests at frequencies of 500-3000 Hz. The patient was not using any other drugs and was reported to show significant improvement in audiometric tests 2 weeks after discontinuation of the drug. According to the Naranjo possibility scale, toxicity was probable. ${ }^{[11]}$ In another study of 12 patients who used acitretin for hidradenitis suppurativa, one patient described tinnitus, which disappeared after discontinuation of therapy. Repeated treatment with acitretin caused tinnitus to recur and the therapy had to be terminated. ${ }^{[12]}$ In a study by Aydogan et al., no significant difference was found between auditory evoked potentials before and after isotretinoin therapy, but the authors stated that it was at subclinical levels. This test is non-invasive and may be useful in detecting subclinical auditory side effects after isotretinoin therapy. ${ }^{[13]}$

Nikiforidis et al. studied auditory brainstem responses in patients treated with oral isotretinoin and found prolonged latency and decreased peaks in three patients, albeit the decreases were not statistically significant. The authors thought that this effect of isotretinoin may have been due to defects in synaptic transmission or malfunction of the auditory nerve fibers. ${ }^{[14]}$ Karabulut et al. evaluated audiometry results at 1,2 and 3 weeks posttreatment and found improved hearing thresholds. Changes in audiometric frequencies were observed at medium and high frequencies $(500-10,000 \mathrm{~Hz})$ in the first week, at a low frequency $(250 \mathrm{~Hz})$ in the second week and at ultrahigh frequencies $(10,000-20,000 \mathrm{~Hz})$ in the third week. ${ }^{[15]}$ Audiometric tests were spread throughout the treatment process in our study. We found sensorineural hearing loss during the tests at 3 and 6 months, and the decreases were found to be statistically significant. Karlidag et al. investigated the relationship between blood lipid levels and functions of hearing in 2002 and found a significantly higher than average hearing level, especially at hearing frequencies of $2000 \mathrm{~Hz} .{ }^{[9]}$ Thakur et al. evaluated the brainstem auditory evoked potentials in patients with hyperlipidemia in two groups with equal pure tone levels. Significant changes were identified in all waves except the first wave and in 3-5 inter-peak latencies. Based on the results of the study, the authors claimed that LDL may play a role in hearing dysfunction. ${ }^{[10]}$ Kojima et al. stated that antihyperlipidemic treatment showed a significant improvement at certain frequencies in patients with hyperlipidemia and sudden hearing loss that started more than 1 month before. ${ }^{[16]}$ In a study conducted in 2007 , Sutbas et al. applied a low-cholesterol diet and antihyperlipidemic therapy to patients with hearing loss associated with exposure to loud noise and to tinnitus patients. The treatment lowered cholesterol levels, improved high-frequency hearing and significantly improved tinnitus scores. ${ }^{[17]}$

In an animal study, long-term and high levels of hypercholesterolemia have negative effects on auditory functions and on the functioning cochlea. ${ }^{[18]}$

In their studies of hearing in large numbers of patients, Jones and Davis claimed that high blood lipid levels have no effect on hearing, and that hyperlipidemia plays no significant role in patients with sudden hearing loss. ${ }^{[1,20]}$ In 2000, a study conducted in patients with high levels of cholesterol showed higher levels of hearing. ${ }^{[2]}$

In our study, treatment with isotretinoin increased total cholesterol and triglyceride levels. These results are consistent with the literature. Isotretinoin reduced puretone hearing at the end of the 6th month and this effect was related to the increases in triglyceride and total cholesterol levels. Both were found to be statistically significant. We thus conclude that isotretinoin affects hearing levels, as well as triglyceride and cholesterol levels. Elevated blood lipid levels have been associated with the disruption of hearing. These two effects may be simultaneous side effects of the drug and may be indirect consequences of the increased blood lipid levels. More comprehensive studies are needed to confirm this.

\section{References}

1. Layton A. The use of isotretinoin in acne. Dermatoendocrinol 2009;1:162-9

2. Freedberg IM, Eisen AZ, Wolff K, Austen KF, Goldsmith LA, Katz SI. Fitzpatrick's dermatology in general medicine. 6th ed. New York: McGraw-Hill; 2003.

3. Orfanos CE, Zouboulis CC, Almond-Roesler B, Geilen CC. Current use and future potential role of retinoids in dermatology. Drugs 1997;53:358-88.

4. Kanigsberg N, DesGroseilliers JP. Use of 13-cis-retinoic acid in cystic acne. Can Med Assoc J 1983;129:224,228.

5. Altman RS, Altman LJ, Altman JS. A proposed set of new guidelines for routine blood tests during isotretinoin therapy for acne vulgaris. Dermatology 2002;204:232-5.

6. Mahasitthiwat V. A woman with sudden bilateral sensorineural hearing loss after treatment psoriasis with Acitretin. J Med Assoc Thai 2005;88 Suppl 1:S79-81. 
7. Tallab T, Joharji H, Jazei M, Bahamdan K, Ibrahim K, Karkashan E. Isotretinoin therapy: any need for laboratory assessment? West Afr J Med 2004;23:273-5.

8. Bigby M, Stern RS. Adverse reactions to isotretinoin. A report from the Adverse Drug Reaction Reporting System. J Am Acad Dermatol 1988;18:543-52.

9. Karlidă $\breve{~ T, ~ A c ̧ i k ~ Y, ~ K a y g u s u z ~ I, ~ Y a l c ̧ i n ~ S, ~ G u ̈ n g o ̈ r ~ M Y, ~ D e m i r b a g ̆ ~}$ E. The effect of hyperlipidemia on hearing function. Kulak Burun Bogaz Ihtis Derg 2002;9:112-6.

10. Thakur JS, Mohindroo NK, Vasanthalakshmi MS, Kashyap N, Azad RK, Sharma DR. Auditory brainstem evoked responses in hyperlipidaemia: effect of various lipid fractions on auditory function. J Laryngol Otol 2012;126:249-56.

11. Rosende L, Verea-Hernando MM, de Andrés A, et al. Hypoacusia in a patient treated by isotretinoin. Case Report Med 2011; 2011:789143.

12. Boer J, Nazary M. Long-term results of acitretin therapy for hidradenitis suppurativa. Is acne inversa also a misnomer? $\mathrm{Br} \mathrm{J}$ Dermatol 2011;164:170-5.

13. Aydogan K, Turan OF, Onart S, Yazici B, Karadogan SK, Tokgoz N. Neurological and neurophysiological effects of oral isotretinoin: a prospective investigation using auditory and visual evoked potentials. Eur J Dermatol 2008;18:642-6.

14. Nikiforidis G, Tsambaos D, Karamitsos D, Koutsojannis C, Georgiou S. Effects of oral isotretinoin on human auditory brainstem response. Dermatology 1994;189:62-4.
15. Karabulut H, Karadag AS, Acar B, et al. The effect of oral isotretinoin (13-cis retinoic acid) on hearing systems in patients with acne vulgaris: a prospective study. Int J Dermatol 2011;50: 1139-41.

16. Kojima Y, Ito S, Furuya N. Hearing improvement after therapy for hyperlipidemia in patients with chronic-phase sudden deafness. Ann Otol Rhinol Laryngol 2001;110:105-8.

17. Sutbas A, Yetiser S, Satar B, Akcam T, Karahatay S, Saglam K. Low-cholesterol diet and antilipid therapy in managing tinnitus and hearing loss in patients with noise-induced hearing loss and hyperlipidemia. Int Tinnitus J 2007;13:143-9.

18. Satar B, Ozkaptan Y, Sürücü HS, Oztürk H. Ultrastructural effects of hypercholesterolemia on the cochlea. Otol Neurotol 2001;22: 786-9.

19. Jones NS, Davis A. A prospective case-control study of 50 consecutive patients presenting with hyperlipidaemia. Clin Otolaryngol Allied Sci 2001;26:189-96.

20. Jones NS, Davis A. A prospective case-controlled study of patients presenting with idiopathic sensorineural hearingloss to examine the relationship between hyperlipidaemia and sensorineural hearing loss. Clin Otolaryngol Allied Sci 1999;24:531-6.

21. Jones NS, Davis A. A retrospective case-controlled study of 1490 consecutive patients presenting to a neuro-otology clinic to examine the relationship between blood lipid levels and sensorineural hearing loss. Clin Otolaryngol Allied Sci 2000;25:511-7.

This is an open access article distributed under the terms of the Creative Commons Attribution-NonCommercial-NoDerivs 3.0 Unported (CC BYNC-ND3.0) Licence (http://creativecommons.org/licenses/by-nc-nd/3.0/) which permits unrestricted noncommercial use, distribution, and reproduction in any medium, provided the original work is properly cited.

Please cite this article as: Boztepe OF, Alan S, Gün T, Özcan KM, Gür ÖE. Hearing loss in patients using isotretinoin: is it a side effect or due to hyperlipidemia? J Med Updates 2013;3(2):82-86. 